\title{
Scenario Analysis of Profits in Further Processing Lumber to Furniture in Ghana for Export: A Case Study of a Local Firm
}

\author{
Peter Kessels Dadzie ${ }^{1, ~ *, ~ K w a s i ~ F r i m p o n g-M e n s a h ~}{ }^{2}$, Martin Amoah $^{3}$, Ernest Boampong ${ }^{4}$ \\ ${ }^{1}$ Interior Architecture and Furniture Production Department, Kumasi Polytechnic, Kumasi, Ghana \\ ${ }^{2}$ Faculty of Renewable Natural Resources, Department of Wood Science and Technology, Kwame Nkrumah University of Science and \\ Technology, Kumasi, Ghana \\ ${ }^{3}$ Faculty of Technical Education, University of Education Winneba, Kumasi Campus, Kumasi, Ghana \\ ${ }^{4}$ Interior Architecture and Furniture Production Department, Kumasi Polytechnic, Kumasi, Ghana
}

Email address:

pkkdadzie@yahoo.com (P. K. Dadzie), peter.kdadzie@kpoly.edu.gh (P. K. Dadzie), frimpongmensahk@yahoo.com (K. Frimpong-Mensah), martamoah@yahoo.com (M. Amoah), Boampongernest43@yahoo.com (E. Boampong), ernest.boampong@kpoly.edu.gh (E. Boampong)

\section{To cite this article:}

Peter Kessels Dadzie, Kwasi Frimpong-Mensah, Martin Amoah, Ernest Boampong. Scenario Analysis of Profits in Further Processing Lumber to Furniture in Ghana for Export: A Case Study of a Local Firm. International Journal of Business and Economics Research. Vol. 4, No. 2, 2015, pp. 55-66. doi: 10.11648/j.ijber.20150402.15

\begin{abstract}
Scenario analysis was used to investigate whether incurring extra costs towards adding value to lumber through further processing is an economically viable venture or not. In-factory study, observations, records review and interviews were used to collect data on costs and incomes relating to lumber and furniture production and exports. The accounting rule for decisions to sell or further process a semi-processed product at the split-off-point was used to assess the profit level under each of five scenarios developed. Results revealed that, it costs $€ 1,336\left(66.80 \%\right.$ of FOB value $/ \mathrm{m}^{3}$ of furniture) to convert kiln-dried lumber to $1 \mathrm{~m}^{3}$ of garden furniture which yields income of $€ 2,073.13 / \mathrm{m}^{3}$. Scenario analyses indicated that, $1 \mathrm{~m}^{3}$ of garden furniture in general could yield additional incomes in the range of $€ 66.077$ to $€ 334.414$ representing $12.4 \%$ and $62.7 \%$ respectively over the export values of lumber used. Three species (odum, mixed redwood and teak) were profitable with mixed redwood and teak respectively obtaining the highest (from $48.14 \%$ to $123.63 \%$ ) and the lowest (from $37.59 \%$ to $9.44 \%$ ) additional profits in relation to the FOB value of their kiln-dried lumber. In conclusion, maintaining costs and increasing production volumes appeared to be the best scenario for higher profits in furniture production. Also, further processing lumber to garden furniture for export appear profitable and should be encouraged as an economic decision towards high revenue generation. It was recommended that the three profitable wood species should be considered for plantations by stakeholders in the afforestation and reforestation of degraded forests in Ghana to ensure their continuous availability for the furniture industry.
\end{abstract}

Keywords: Ghana Furniture Production, Costs and Profits, Scenario Analysis, Furniture and Lumber FOB Values, Wood Species in Ghana

\section{Introduction}

Furniture produced in Ghana for exports is mainly garden furniture [1]. Such furniture products are mostly used in open places where they are partly or wholly exposed to the weather and as such are primarily produced from relatively durable and weather resistant wood species like Milicia excelsa (iroko/odum), Khaya spp. (mahogany), Tectona grandis (teak), Entandrophragma utile (utile) and Albizia ferrugenea (albizia) either alone or in combination with some metal components [2-3]. But wood has been the most favorite material for garden furniture globally due to its desirable attributes such as: easy workability when using both hand and machine tools; ability to be fastened satisfactorily with adhesives, nails and screws; natural beauty from variations in figure and colour that blends; and resistance to rust and corrosion [4-5]. In Ghana, 26 wood species have been identified as being used for the production of various garden furniture parts for exports [6]. These species in addition to others are also being exploited 
for lumber production for exports and for local markets.

It is however worth mentioning that kiln-dried lumber is a semi-processed product that can be sold in its form or much value can be added to it through further processing into tertiary products like garden furniture and hence, lumber is said to be a product at a split-off-point [7]. Meanwhile, additional cost of other materials (fittings, adhesives etc), labour and other expenses would have to be incurred beyond what was incurred in producing the kilndried lumber. These additional (differential) costs are the focus when accounting for further processing a product at the split-off-point. However, this accounting procedure requires that the value of the product at split-off-point, supposing it was sold, becomes the raw material cost for the product to be obtained at the end of further processing [7-8], which in this case, is garden furniture. Moreover, in such studies, scenario analysis is employed to study the lower and upper limits of variables and also to avoid the presentation of a single number as the sole estimates of profits so as to deal with uncertainties [9]. This further aids decision makers to observe the group of factors under which the proposed project performs best or worst [7, 9]. In forestry studies however, operational costs (including labour, machinery, overheads and materials) are based on average costs which are assumed to be actual costs [10]. But these operational costs can be influenced by a number of factors in the production process.

One important factor that affects raw material cost in any production process is recovery rate or conversion efficiency [11]. This is because the raw material cost depends heavily on recovery rate since all recovered materials and the waste generated from the conversion process form part of the cost of material purchased [11]. A preliminary study found conversion efficiency in further processing kiln-dried lumber to garden furniture in Ghana to be about 59\% [6] implying that about $41 \%$ of kiln-dried lumber bought could be lost to waste out of which about $39 \%$ may not be recovered for any income to defray part of the cost of raw materials and therefore becomes a loss. Hence, recovery rate has great influence on the profit margins to be made in wood products manufacturing [11]. However, recovery rate is a function of log shape and size, defects, and efficiency of equipment and personnel, and it has a great influence on the profit margins to be made on a particular wood product produced [12-13]. Hence recovery rate in converting lumber to garden furniture could have a negative influence on additional value/profit relative to what should have been obtained from selling lumber in its form, especially when the factors that affect recovery rate are not managed properly and also when the additional value of the furniture produced is not much.

But in the export market however, furniture parts have much higher value per unit volume than lumber. Trade statistics from the records of Timber Industry Development Division (TIDD) reveal that, while a cubic meter of kilndried lumber was $€ 377.172$, air-dried $€ 315.133$ and overland was $€ 68.578$ on the average, the value of garden furniture parts stood at $€ 1,677.850$ per $\mathrm{m}^{3}$ [14]. These show value differences between furniture and air-dried lumber per $\mathrm{m}^{3}$ to be $€ 1,362.717(432.43 \%)$ and that between furniture and kiln-dried lumber to be $€ 1,300.717$ (344.85\%). Additionally, individual wood species, when converted to garden furniture for exports could register appreciably higher values than when exported in the lumber form. For instance, kiln-dried lumber of mahogany (Khaya spp.) and its furniture values registered an increase of $200.07 \%$, while odum (Milicia excelsa) recorded a value increase of $178.10 \%$ [14]. These appear to confirm that, in the forest product industry, garden furniture (a tertiary wood product) offers much better value addition option for profit making than lumber (a secondary wood product) in the wood products export mix. Additionally, garden furniture employs much more workers than lumber per firm, out of the over 100,000 direct employments that the forests provide in Ghana, possibly due to the many processes involved [15-17].

It is therefore not out of place to view furniture production as one wood product that could largely improve the economic fortunes of both individuals and the country at large. However, in spite of these potential benefits and profits of garden furniture production, only a few of Ghana's wood processing companies are into furniture production for exports [18]. Out of over 200 firms in the wood processing sector in Ghana by 2003, only 5 of them produced garden furniture for exports. Unfortunately, by December 2005, this number of garden furniture firms had reduced to only $2[13-14,19]$ and none appears to be exporting furniture currently. The question then is 'does the cost of further processing kiln-dried lumber to garden furniture render the process unprofitable, for which reason the firms are disappearing?

One reason that could be ascribed to the apparent disappearance of the existing furniture producing firms and the seeming disinterest in new firms to go into further processing lumber to furniture is lack of organized information in literature regarding expected profits (i.e. after factoring recovery rate and differential costs), the possible best combination scenarios of various costs and production volumes that could yield much profit. Previous related study by [6] revealed that further processing kilndried lumber of individual wood species to furniture could yield additional incomes from the least of $46.37 \%$ (for emire) to the highest of $440.66 \%$ (for akasaa). However, the authors factored only recovery rate in their analysis and did not consider any cost of production. Again the study did not consider varied scenarios to ascertain which combination of costs and volumes of production can yield the most profit. These are necessary because, one major economic decision rule is that projects that add more to revenue than cost should be undertaken whereas the reverse should not, if profit is to be made [20]. Hence, there are still some unanswered questions such as; 'does the cost of processing kiln-dried lumber to furniture make furniture production unprofitable? And what combination of costs and volumes of production could yield much profit? It is therefore 
necessary that the appropriate accounting or costing procedure is employed to factor the production cost of furniture into various scenarios for further analysis to determine whether or not furniture production is really profitable.

Another reason for the extinction of furniture manufacturing firms in Ghana could be the stiff competition among wood processing firms for the same timber species which are also disappearing and are scarce in supply as a result of deforestation. It is reported that within the last century alone, Ghana's forests cover has reduced from 8.3 million ha to 1.7 million ha [21]. The disturbing aspect of this trend is that the high valued commercial timber species which are also desirable for furniture production is projected to reduce by a further $50 \%$ [22]. Incidentally, the wood species that provide high furniture value also provide high lumber value in the export market [6] and this appears to provide some kind of incentive for competition for the species. As a result, Government of Ghana in her effort at ensuring timber availability has given a 40year contract to "Form Ghana" (an afforestation firm) to engage in afforestation, reforestation and regeneration of 15,000 ha of degraded forests in Ghana. This study could provide some information as to the wood species that could yield much profit in value-added products such as garden furniture which has much economic benefits than lumber. The broad objective of this study is therefore three-fold: First is to estimate income of producing garden furniture in general and for some specific species. Second is to estimate the total cost of producing garden furniture in general and for some specific species, and third to perform scenario analysis to estimate profits in further processing kiln-dried lumber in general, and for some selected species, to garden furniture.

\section{Materials and Methods}

\subsection{Research Design}

The study covered a three-year period from January 2003 to December 2005. This period was dictated by the availability of information on costs as could be provided by the local firm (name withheld for confidentiality and anonymity) used for this case study. This firm has existed since 1969 and holds an average of over 90\% of garden furniture exports from Ghana. In-factory study, observations, records review and interviews were the main tools used to collect relevant data and costing of garden furniture. The differences in revenue between selling the product at the split-off-point (i.e, as kiln-dried lumber) and that at the end of further processing (in the form of garden furniture) were collected. These were compared with the collected differential cost of further processing (i.e, differential elements of processing costs, selling and distribution costs, and taxes) in relation to kiln-dried lumber and garden furniture as demanded by accounting rules on decisions to sell or further process a semi-processed product at the split- off-point [8]. For all the analyses of costs, revenues and profits; averages of the study period for Ghana's inflation and 91 days Treasury bill rates of $18.18 \%$ and $20.31 \%$ respectively and exchange rate of $€ 1 \equiv$ Gh $\varnothing 1.140$ were used.

\subsection{Data Collection}

\subsubsection{Incomes (Values) of Garden Furniture}

The incomes from garden furniture production were obtained from two component sources, namely the export value or Free-On-Board (FOB) and the by-product income, otherwise called 'other income'. The average FOB values of garden furniture $/ \mathrm{m}^{3}$ from each wood species were extracted from TIDD's export reports on wood products [3, 18-19]. In estimating the average values $/ \mathrm{m}^{3}$ of garden furniture in general, the cumulative values were also divided by the cumulative volumes of garden furniture exported. These values (average value $/ \mathrm{m}^{3}$ of garden furniture in general and for specific wood species) were taken as the export income/value after further processing kiln-dried lumber to garden furniture in general, and for the specific wood species respectively. These were used as such for the economic/profitability analysis.

Annual average value for all the by-products (also called 'other income') from the company's manufacturing processes including sales of substandard products that were not exported, and for that matter were not recorded in the TIDD's export reports [3, 18-19], were extracted from the local company's financial statements covering the study period. However, the company produces parquet flooring in addition to garden furniture but income from by-products is not separated for the two products. Hence, the mean volume $\left(\mathrm{m}^{3}\right)$ of parquet flooring exported by the company was also extracted from the TIDD's export reports [3, 18-19]. These mean volume and the mean volume of garden furniture were put together and each expressed as a percentage of the total. These percentage proportions of each of the products were used as the bases for sharing/apportioning the 'other income' [7, 23-24]. Thereafter, the portion of 'other income' together with the FOB value for garden furniture represented the total value realised from garden furniture production activities.

\subsubsection{Total Cost of Further Processing Kiln-Dried Lumber to Garden Furniture for Export}

The components of the differential/incremental cost of further processing kiln-dried lumber into garden furniture for export included material, processing/production, and selling and distribution or marketing costs.

\section{(i) Materials Cost}

Material cost was divided into two, namely raw materials cost (FOB value of kiln-dried lumber), and 'other materials' cost (cost of screws, adhesives and packaging) used to produce garden furniture.

The raw material (kiln-dried lumber) cost, in accounting for further processing, is the FOB value/income to have been obtained from lumber if it had been exported in its state. Hence, mean export (FOB) values for kiln-dried lumber in 
general and for specific wood species being used for furniture production were extracted from the TIDD's export report [3, 18-19] on wood products. The raw material costs for garden furniture in general and for specific wood species were thereafter estimated by multiplying the average FOB value for lumber and the total lumber volume $\left(\mathrm{m}^{3}\right)$ used to produce garden furniture.

Average 'Other Materials' costs were calculated as percentages of the FOB values for garden furniture. These were computed on six (6) sets of cost calculation sheets (obtained from the study company) of 6 different furniture types. These six different furniture types were the same as the ones used for the determination of efficiency/recovery rate of converting kiln-dried lumber to garden furniture. Each set, however, consisted of 10 furniture pieces of same type. Therefore 60 (i.e. 6 sets of 10) were used in this calculation using the relation expressed in equation 1 -modified from [23-25].

$$
\text { 'Other Materials' Cost }(\%)=\frac{\text { Other Materials cost in Furniture }}{\text { FOB Value for Furniture }} \times 100 \%
$$

This average percentage value was then multiplied by the annual average value of furniture sold (export plus local) to obtain the annual average total cost of 'other materials' in monetary terms [25]. This annual cost was subsequently divided by the annual average volume $\left(\mathrm{m}^{3}\right)$ of furniture sold to obtain the average 'other materials' cost $/ \mathrm{m}^{3}$.

\section{(ii) Production/Processing Cost}

Processing cost was divided into two, namely labour and 'other expenses' costs. The labour cost comprised all expenditure on employees (i.e. wages, salaries and other emoluments), whereas 'other expenses' consisted of other costs besides materials and labour. Both labour and expenses costs were extracted from the local study company's financial statements from 2003 to 2005 . The averages were estimated to represent those costs in the company.

\section{(iii) Selling and Distribution (or Marketing) Costs}

The differences of the selling and distribution (or marketing) costs, and taxes that related to producing and exporting garden furniture or lumber were estimated through interviews of experts and review of the local study company's financial statements, and used in the scenario analyses. The experts interviewed included the Director of Internal Revenue Service and TIDD District Manager.

\subsection{Data Analyses}

\subsubsection{Incomes (Values) of Garden Furniture}

The portion of 'other income' that was added to the FOB value/income to make up the total value/income for garden furniture was either maintained at its level or completely eliminated in some instances of the scenario analyses. Moreover, at some instance, the portion due to parquet flooring was added to that of garden furniture. All these were done to assess the influence of the 'other income' on profit levels.

\subsubsection{Total Cost of Further Processing Kiln-Dried Lumber to Garden Furniture for Export}

The company used for this study produces two different products (garden furniture and parquet flooring) using the same workers, equipment and other production facilities for both products. The company also sells all substandard products from the production of both products but no separation was made in the financial statements used to extract costs and 'other incomes' as to the portions that belonged to each of the products. As a result, besides the direct materials (lumber and other materials costs), all other costs were taken as 'common costs' to the two products which needed to be apportioned or shared for them (base case scenario) using established bases of apportionment [7, 23-24, 26]. These bases were percentage of average number of workers operating some specialized machines for the 2 products and percentage annual volume of each product produced, for sharing labour costs and other expenses respectively [7, 27]. Afterwards, the portions due to garden furniture production were divided by the estimated annual average volume of garden furniture produced and sold to determine the average labour cost $/ \mathrm{m}^{3}$ and expenses cost $/ \mathrm{m}^{3}$. However, in the profitability scenario analyses, besides sharing these costs amongst the two products of the company, they were also either wholly attributed to garden furniture only or completely eliminated to assess how they affect profit levels.

\subsubsection{Profitability of Further Processing Lumber to Garden Furniture}

\section{(i) Scenario Analyses}

Five (5) scenarios or assumptions were adopted to ascertain the profitability or otherwise of garden furniture production. These were based on a cost-volume-profit relation $\{$ REQUIRED VOLUME X UNIT PRICE $=$ TOTAL COST + TARGETED NET PROFIT PER UNIT\} [7, 11, 27]. The five (5) assumptions/scenarios were:

Scenario 1- (Base Case) (S1) - If total differential processing costs and other incomes were shared amongst the company's two products, according to the established bases, what would happen to profit?

Scenario 2(S2)- If the total differential labour costs were attributed to only garden furniture manufacturing (labour cost was increased by the share of parquet flooring- $16.5 \%$ Table 3.3), while volume of furniture produced, 'other expenses', and 'other income' remained constant at S1 levels, what would happen to profit?

Scenario 3(S3) -If the total differential 'other expenses' were attributed to only garden furniture manufacturing (on the assumption that all expenses were incurred because of garden furniture production, and therefore this cost was increased by the percentage portion obtained by parquet flooring-16.5\%), while labour, 'other income' and the volume of furniture produced remained constant at Scenario 1 levels, what would happen to profit?

Scenario 4(S4) - If the total differential costs (labour and expenses together) of the company were directed towards 
the production of garden furniture only. In other words if both labour costs and expenses were increased simultaneously by the percentage share of parquet flooring $(16.5 \%)$, while 'other income' and volume of garden furniture produced remained unchanged at the base (Scenario 1) level, what would happen to profit?

Scenario 5 (S5) - If volume produced and sold was increased by the percentage annual volume of parquet flooring on the assumption that, only the portion of labour and other expenses for garden furniture were employed (i.e., costs maintained at Scenario 1 levels) but productivity was increased to the level of furniture and flooring together (i.e. volume increased by $16.5 \%$ ), what would happen to profit?

In ascertaining the economic viability (benefit-cost analyses) of converting specific wood species' lumber to garden furniture, data on nine different wood species were used. These included odum (Milicia excelsa), dahoma (Piptadeniastrum africanum), emire (Terminalia ivorensis), teak (Tectona grandis), mixed redwood, mahogany (Khaya spp.), avodire (Turraeanthus africanus), albizia (Albizia ferruginea) and akasaa (Chrysophyllum spp.). Selection of these species was based on the regular appearance of their furniture in the export market. However, when working on these species, it was assumed that all of them incurred the same amount of labour and other expenses costs in their processing, and also obtained the same value from the sale of by-products ('other income').

The economic viability (cost-benefit analyses) in further processing kiln-dried lumber to garden furniture for export were done by following the accounting procedure for analysing decisions to sell or further process a product at the split- of-point (Plate 1) [7].
Raw material cost (FOB value of lumber-KD)

Less marketing cost \& Taxes (14.42\%)

Add incremental/differential costs:

Cost of other materials $/ \mathrm{m}^{3}$

Labour cost $/ \mathrm{m}^{3}$

Other Expenses $/ \mathrm{m}^{3}$

Total average cost of producing $1 \mathrm{~m}^{3}$ of garden furniture

Average FOB value of furniture $/ \mathrm{m}^{3}$

Less marketing cost \& Taxes (13.42\%)

Add other income

Total average income from sale of $1 \mathrm{~m}^{3}$ of garden furniture

Average additional income for producing garden furniture

Average percentage of additional income on furniture over lumber $=(\mathrm{F} \div \mathrm{A} \times 100 \%)$
$€$

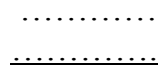

............

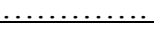

............

….......
(B)

(A)

$€$

$$
\begin{array}{rr}
\text { Garrison }(1991)^{[7]} \\
\hline
\end{array}
$$

Plate 1. Accounting for decision to sell kiln-dried lumber or further process it to garden furniture before export.

\section{(ii) Time Value of Money}

The money invested to further process kiln-dried lumber to garden furniture in respect of each of the five assumptions (scenarios) used for analyses were compounded using the formula presented in Equation 2;

$$
\mathrm{S}=\mathrm{P}(1+\mathrm{r})^{\mathrm{n}}
$$

Where: $\mathrm{P}=$ Invested amount (income that a producer would have obtained from lumber export + differential labour costs and expenses incurred), $r=$ interest rate (risk-free rate) expressed in decimals, $\mathrm{n}=$ period of investment (number of months or weeks) and $\mathrm{S}=$ total sum (including interest) after ' $n$ ' period $[26,28]$. The risk-free rate of return (r) was also determined using Equation 3,

Risk-free rate $(\mathrm{r})=[(1+$ real rate $) \times(1+$ inflation $)]-1$

$$
1+\mathrm{R}=(1+\mathrm{r}) \times(1+\mathrm{h})
$$

Where: $\mathrm{R}=$ nominal rate (average of 91 day Treasury bill rate per annum), $r=$ real rate (rate for a day, week, month etc) and $\mathrm{h}=$ average Inflation rate [26-27].

\section{Results}

\subsection{Incomes (Values) of Garden Furniture}

Recovery rates are important in understanding incomes and costs in wood products production. Table 1 presents mean recovery rates of eleven wood species and garden furniture. Generally recovery for converting kiln-dried lumber to garden furniture was reported to be $59.07 \%$ and ranging from the lowest of $51.60 \%$ (avodire) to the highest of $65.97 \%$ (odum) [6].

However, the real rate was also found using equation 4 
Table 1. Experimental Results on Mean Recovery Rates-RR (\%) of Eleven (11) Wood Species.

\begin{tabular}{|c|c|c|c|c|c|c|c|c|c|c|c|}
\hline Wood Species & odum/Iroko & Mixed Red-woods & Teak & Mahogany & Afromosia & hyedua & Avodire & dahoma & Albizia & Akasaa & emire \\
\hline $\begin{array}{l}\text { Mean Recovery } \\
\text { Rates }(\%)\end{array}$ & 65.97 & 60.90 & 56.10 & 63.78 & 55.87 & 63.97 & 51.60 & 57.35 & 57.23 & 61.69 & 55.28 \\
\hline Standard Deviation & 1.23 & 2.25 & 2.04 & 1.58 & 2.34 & 1.75 & 2.69 & 2.51 & 2.66 & 1.87 & 2.60 \\
\hline \multicolumn{12}{|c|}{ General Average Recovery Rate $=\left\{\left(\sum \mathrm{RR}\right) / 11\right\}=59.07 \% \pm 4.47$} \\
\hline
\end{tabular}

Source: Dadzie et. al. (2014) ${ }^{[6]}$

Plate 2 shows incomes and volumes of garden furniture and kiln-dried lumber computed by considering the recovery rates (Table 1) where necessary. From Plate 2, garden furniture generally registered an average FOB value of $€ 2,000.050$ equivalent to $\mathrm{GH} \phi 2,280.057$. This value was the general average income obtained from export of $1 \mathrm{~m}^{3}$ of garden furniture after value addition. There was also 'other income' of $€ 73.078 / \mathrm{m}^{3}$, implying that furniture production could yield a total average income of $2,073.128 / \mathrm{m}^{3}$.
Annual Average Volume of Furniture Sold (Export)

Annual Average Volume of Furniture Sold (Local-2.0\%)

Annual Average Total Volume of Furniture Sold (Total Output)

Average Total Lumber (KD) used (Input; -Average Recovery $=59.07 \%$ )

Thus;

$1 \mathrm{~m}^{3}$ of Furniture is $59.07 \%$ of vol. of lumber used (i.e. lumber used $=1 \mathrm{X} 100 \% \div 59.07 \%$ )

Average FOB Value $/ \mathrm{m}^{3}$ of Lumber (Raw Material Cost $/ \mathrm{m}^{3}$ )

Hence;

Average FOB Value of Lumber to Produce $1 \mathrm{~m}^{3}$ furniture (367.997 X 1.693)

Less average Total Selling and Distribution Costs plus Taxes (14.42\% of 623.019)

Average expected Income from sale of $1.693 \mathrm{~m}^{3}$ of Lumber (i.e raw materials cost of $1 \mathrm{~m} 3$ of furniture)

Average FOB Value $/ \mathrm{m}^{3}$ of Furniture (income after further processing)

Less average Additional differential Selling \& Distribution Cost

Average Expected Income from sale of $1 \mathrm{~m}^{3}$ of Furniture

Annual Average Total 'Other Income' for Furniture

Average 'other income' $/ \mathrm{m}^{3}\left(€ 146,267.990 \div 2001.532 \mathrm{~m}^{3}\right)$

Average Value $/ \mathrm{m}^{3}$ of furniture (Total income $=2,000.050+73.078$ )

$$
\begin{aligned}
& =1,961.502 \mathrm{~m}^{3} \\
& \begin{array}{r}
=40.030 \mathrm{~m}^{3} \\
\underline{\underline{=2,001.532 \mathrm{~m}^{3}}}
\end{array} \\
& =3,388.410 \mathrm{~m}^{3} \\
& =1.693 \mathrm{~m}^{3} \\
& =€ 367.997 \\
& =€ 623.019 \\
& =€ 89.839 \\
& =€ 533.180 \\
& =€ 2,000.050 / \mathrm{m}^{3} \\
& =€ 178.568 / \mathrm{m}^{3} \\
& =€ 1,821.482 / \mathrm{m}^{3} \\
& =€ 146,267.990 \\
& =€ 73.078 / \mathrm{m}^{3} \\
& =2073.128 / \mathrm{m}^{3}
\end{aligned}
$$

Sources: TIDD, $2003^{[3]} ; 2004^{[14]} ; 2005^{[18]}$; and financial statements of Study Company for 2003 to 205.

Plate 2. Summary results on volumes and incomes/values of lumber and garden furniture.

\subsection{Total Cost of Further Processing Kiln-Dried Lumber into Garden Furniture for Export}

\subsubsection{Materials Cost}

Plate 2 revealed that the annual average value $/ \mathrm{m}^{3}$ of kilndried lumber was $€ 367.997$ (GHф 419.517). This value of lumber, therefore, was the raw material (lumber) $\operatorname{cost} / \mathrm{m}^{3}$ for the production of garden furniture, in general. Hence, with the average recovery rate of $59.07 \%$ (Table 1) for converting kiln-dried lumber to garden furniture in general, which meant that $1.693 \mathrm{~m}^{3}$ of lumber was needed to produce $1 \mathrm{~m}^{3}$ of garden furniture, the FOB value of kiln-dried lumber needed to produce $1 \mathrm{~m}^{3}$ of garden furniture is $€ 623.019$ ( $€ 367.997 \mathrm{x}$ $\left.1.693 \mathrm{~m}^{3}\right)$. Upon deducting selling and distribution cost, and taxes, the actual raw material cost to be absorbed into further processing lumber to garden furniture was $€ 533.180$. Meanwhile the raw material (lumber) costs for specific wood species were as presented in Table 2. Among the ten selected individual wood species used for the production of garden furniture in Ghana, odum (Milicia excelsa) lumber had the highest average value of $€ 657.26 / \mathrm{m}^{3}$ equivalent to $\mathrm{Gh} \phi 749.276 / \mathrm{m}^{3}$. Regarding garden furniture, amongst all the wood species, teak had the highest average value of $€ 2,530.180 / \mathrm{m}^{3}\left(\mathrm{GH} \notin 2,884.405 / \mathrm{m}^{3}\right)$, whereas albizia (Albizia ferruginea) garden furniture had the least average value of $€ 792.950 / \mathrm{m}^{3}$ equivalent to $\mathrm{Gh} \varnothing 903.963 / \mathrm{m}^{3}$. "Other materials' cost was found to be $€ 323.808 / \mathrm{m}^{3}$ (Table 3). Hence total materials cost (raw materials + 'other materials' costs) amounted to $€ 856.988$ (i.e. $€ 533.180+€ 323.808$ ) for garden furniture in general, whereas that for each specific species depended on its lumber FOB value or $\cos t / \mathrm{m}^{3}$ and its recovery rate. 
Table 2. Annual average values (FOB) $/ \mathrm{m}^{3}$ of lumber and garden furniture from nine different wood species in Euros ( $€$ ).

\begin{tabular}{lcccc}
\hline Species of Wood & $\begin{array}{c}\text { Annual Average. } \\
\text { Values } / \mathbf{m}^{\mathbf{3}} \text { of Lumber }\end{array}$ & $\begin{array}{c}\text { Annual Average Value } \mathbf{m}^{\mathbf{3}} \\
\text { of Garden Furniture }\end{array}$ & $\begin{array}{c}\text { Value Difference } \mathbf{m}^{\mathbf{3}} \\
\text { Between furniture \& lumber }\end{array}$ & $\begin{array}{c}\text { Percentage of value Difference } \\
\text { over lumber value }\end{array}$ \\
\hline Odum/Iroko & 657.26 & $2,473.27$ & $1,816.01$ & 276.30 \\
Dahoma & 323.05 & $1,033.42$ & 710.37 & 219.89 \\
Emire & 391.92 & 961.26 & 569.34 & 145.51 \\
Teak & 624.68 & $2,530.18$ & $1,905.50$ & 305.04 \\
M. Redwood & 252.95 & $1,939.32$ & $1,686.37$ & 666.68 \\
Mahogany & 605.16 & $1,722.89$ & $1,117.73$ & 184.70 \\
Avodire & 355.87 & $1,625.58$ & $1,269.71$ & 356.79 \\
Albizia & 414.31 & 792.95 & 378.64 & 91.39 \\
Akasaa & 525.24 & $1,179.91$ & 654.67 & 124.64 \\
\hline
\end{tabular}

SOURCE: TIDD-Wood Products' Export Report, January 2003 to December, 2005.

\subsubsection{Differential/Incremental Costs of Further Processing Lumber into Furniture}

In respect of Scenario 1 or the base scenario (where all differential costs and other incomes were shared/apportioned among the two products of the company using volume produced, and number of workers as the bases), the sum of the various differential/ incremental costs involved in further processing lumber to garden furniture for export (Labour + Other Expenses + Marketing/selling and distribution and Taxes + Other Materials), in general, amounted to $€ 1,335.958$ per $\mathrm{m}^{3}$ of garden furniture (Table 3). This figure of the incremental/differential cost was equivalent to $66.79 \%$ of the general average FOB value of garden furniture. Hence, there should be, at least, $€ 1,336$ value difference between the kilndried lumber of a species and its garden furniture before profit could be made from furniture of that wood species.

Furthermore, from Table 3, the total incremental/differential costs $(€ 1,335.958)$ represent about $214.43 \%$ of the FOB value (€623.019-Plate 2) of the volume of lumber used to produce the $1 \mathrm{~m}^{3}$ of garden furniture. This means that, in general terms, besides the raw material cost (value of volume of lumber used), further processing of $1 \mathrm{~m}^{3}$ of garden furniture for export would cost additional amount of about $214.43 \%$ of the FOB value of the volume of lumber needed.

Additionally, from Table 3, the total product cost (i.e differential cost + raw materials cost) of $1 \mathrm{~m}^{3}$ of garden furniture summed up to $€ 1,869.138$ representing $93.45 \%$ of the FOB value of garden furniture. It follows then that the additional income to be obtained from further processing the lumber to furniture (if no income was obtained from byproducts) was $€ 131.362$ representing $6.55 \%$ of the FOB value of garden furniture. This amount was also $24.64 \%$ of the FOB income (€533.180) from the sales of the raw material (lumber) that an exporter would have obtained after settling marketing costs and taxes. If the other income was factored, the total additional income would be expected to be $€ 204.440$ representing $38.35 \%$ of the FOB value from lumber sales. These percentages of additional incomes seem quite impressive and attractive.

Table 3. Average Total Differential/Incremental Costs Due to Conversion of Lumber to Garden Furniture.

\begin{tabular}{|c|c|c|c|}
\hline \multirow[b]{2}{*}{ Cost Item } & \multicolumn{3}{|c|}{ Amount Involved (€) } \\
\hline & $\begin{array}{l}\text { Lumber (KD) (value of volume } \\
\text { for } 1 \mathrm{~m}^{3} \text { furniture- } € 623.019 \text { ) }\end{array}$ & $\begin{array}{l}1 \mathrm{~m}^{3} \text { Garden Furniture } \\
(€ 2,000.050)\end{array}$ & $\begin{array}{l}\text { Differential/Incremental Costs \& Their } \\
\text { Percentages in Furniture Value }\end{array}$ \\
\hline Marketing and Taxes & $14.42 \%=89.839$ & $13.42 \%=268.407$ & $178.568(8.93)$ \\
\hline \multicolumn{3}{|l|}{ Labour } & $328.298(16.41)$ \\
\hline \multicolumn{3}{|l|}{ Other Expenses } & $505.284(25.26)$ \\
\hline \multicolumn{3}{|l|}{ Other Materials } & $323.808(16.19)$ \\
\hline \multicolumn{3}{|c|}{ Total incremental/differential cost } & $1,335.958(66.79)$ \\
\hline \multicolumn{3}{|c|}{ Raw material cost (lumber value less marketing cost $\&$ taxes) } & $533.180(26.66)$ \\
\hline \multicolumn{3}{|l|}{ Total Product Cost } & $1,869.138(93.45)$ \\
\hline \multicolumn{3}{|c|}{ Expected additional income (furniture value less Total cost) } & $131.362(6.55)$ \\
\hline \multicolumn{3}{|c|}{ Add other income (income from by-products) } & $73.078(3.65)$ \\
\hline \multicolumn{3}{|l|}{ Total additional income } & $204.440(10.22)$ \\
\hline
\end{tabular}

Source: The case study Local firm (2003-2005) and Internal Revenue Service 2003-2005).

Note: Figures in brackets are percentages in relation to furniture FOB value of (€2000.050-Plate 2$)$. 


\subsection{Profitability of Further Processing Lumber to Garden Furniture}

\subsubsection{Scenario Analyses}

By applying the five Scenarios to the various costs and incomes from further processing lumber to garden furniture, the additional incomes in relation to the general FOB value $(€ 533.180)$ from the sales of the raw material (kiln-dried lumber) that an exporter would have obtained after settling marketing costs and taxes are as presented in Table 4.

Table 4. Additional income after producing and selling garden furniture $(\epsilon) / \mathrm{m}^{3}$ and their percentages in relation to the average FOB value of lumber needed (€533.180)

\begin{tabular}{lcc}
\hline \multicolumn{1}{c}{ Scenarios } & Additional income $/ \mathbf{m}^{\mathbf{3}}(\boldsymbol{\epsilon})$ & Percentage increase \\
\hline Scenario $\left(\right.$ Base case- Volume produced $\left.=2001.532 \mathrm{~m}^{3}\right)$ & 204.440 & 38.35 \\
Scenario 2 $\left(\right.$ Volume produced $\left.=2001.532 \mathrm{~m}^{3}\right)$ & 149.674 & 28.07 \\
Scenario 3 $\left(\right.$ Volume produced $\left.=2001.532 \mathrm{~m}^{3}\right)$ & 120.393 & 22.58 \\
Scenario 4 $\left(\right.$ Volume produced $\left.=2001.532 \mathrm{~m}^{3}\right)$ & 66.077 & 12.39 \\
Scenario 5 $\left(\right.$ Volume produced $\left.=2332.685 \mathrm{~m}^{3}\right)$ & 334.414 & 62.72 \\
\hline
\end{tabular}

From Table 4, generally, further processing kiln-dried lumber to garden furniture is likely to provide additional incomes in the range of $€ 66.077$ (Scenario 4 -the worst case scenario) to $€ 334.414$ (Scenario 5-the best case scenario) for every $1.693 \mathrm{~m}^{3}$ of lumber used to produce and export $1 \mathrm{~m}^{3}$ of garden furniture. Thus, if wood was exported in the lumber

form instead of further processing to garden furniture, all these additional incomes and other benefits of the production venture would be lost.

\subsubsection{Time Value of Money}

Table 5. Compound interests on monies spent in producing $1 \mathrm{~m}^{3}$ of garden furniture at risk-free rate of interest (27.63\% p.a or $0.53 \%$ per week).

\begin{tabular}{|c|c|c|c|c|c|}
\hline \multirow[b]{2}{*}{ Weeks } & \multicolumn{5}{|c|}{ Compound interest $(€)$ on amounts spent under each scenario. } \\
\hline & $\begin{array}{c}\text { Scenario 1 } \\
(\text { Amount- } € 1,690.570)\end{array}$ & $\begin{array}{c}\text { Scenario } 2 \\
\text { (Amount- } € 1,744.886)\end{array}$ & $\begin{array}{c}\text { Scenario } 3 \\
\text { (Amount- } € 1,774.157)\end{array}$ & $\begin{array}{c}\text { Scenario } 4 \\
\text { (Amount- } € 1,828.483)\end{array}$ & $\begin{array}{c}\text { Scenario } 5 \\
(\text { Amount- } € \text { 1,572.237) }\end{array}$ \\
\hline 1 & 8.960 & 9.248 & 9.403 & 9.691 & 8.333 \\
\hline 2 & 17.968 & 18.545 & 18.856 & 19.433 & 16.800 \\
\hline 3 & 27.023 & 27.890 & 28.359 & 29.227 & 25.131 \\
\hline 4 & 36.126 & 37.287 & 37.912 & 39.073 & 33.597 \\
\hline
\end{tabular}

After the total costs of producing $1 \mathrm{~m}^{3}$ of garden furniture were invested at compound interest using the risk-free rate of return $(27.63 \%$ p.a or $0.53 \%$ /week) for periods of $1,2,3$ and 4 weeks (one week more than the 3 weeks maximum period used by the Study Company to complete a garden furniture contract), the amount accrued as interests were as presented in Table 5. The total costs invested comprised the value that the producer would have obtained from export of the total volume of kiln-dried lumber used, monies spent to hire labour, purchase other materials and those used for other expenses to produce the furniture.

However, from Table 5, the compound interest that could be accrued from investing the total cost incurred in producing $1 \mathrm{~m}^{3}$ of garden furniture, at a risk-free rate of return, ranged from $€ 8.333$ (Ghф9.498) after the $1^{\text {st }}$ week to $€ 39.073$ (Ghф44.540) after 4 weeks. These represent $1.56 \%$ and $6.93 \%$ respectively of the value ( $€ 533.180)$, which lumber producer would have obtained from exporting the wood used to produce garden furniture as kiln-dried lumber. Comparatively, these compound interests are nowhere near the found additional incomes that ranged from $€ 66.066$ (GHф75.302) to $€ 334.201$ (GHф380.920) obtained from garden furniture exports (Table 4).

Moreover, Figure 1 represents the scenario analyses on the nine (9) selected different wood species. Only three (3) wood species were found profitable under all the five scenarios or assumptions. The profitable wood species included odum (Milicia excelsa), mixed redwood and teak (Tectona grandis). However, out of the 3 profitable species, mixed redwood garden furniture had the highest percentage of profit margin over its lumber (ranging from $48.14 \%$ to $123.63 \%$ ), if the lumber used to make $1 \mathrm{~m}^{3}$ of its garden furniture was exported as kiln-dried lumber. Teak was found to have the least profit range of about $9.44 \%$ and $37.59 \%$ (Figure 1). The six (6) other wood species registered losses ranging from $18.13 \%$ (avodire at scenario 1) to $-138.14 \%$ (albizia at scenario 4) in all the scenarios. Additionally from Figure 1, it could be observed that scenario 5 appeared to be the best whereas scenario 4 happened to be the worst scenario for achieving much profit or less losses. 


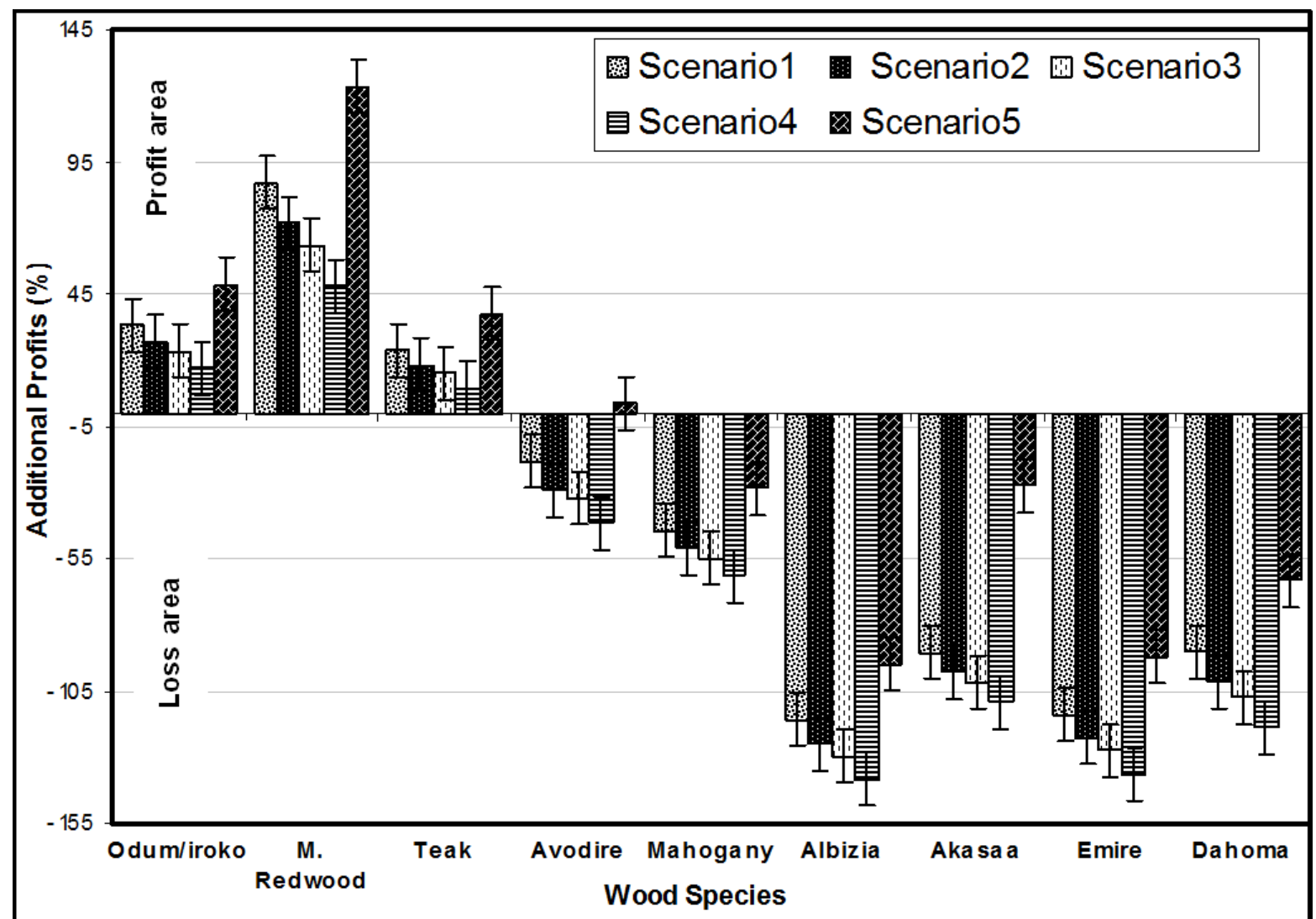

Figure 1. Percentage profits for nine wood species in relation to the income from export of their lumber volumes used to produce $1 \mathrm{~m}^{3}$ of garden furniture.

\section{Discussions}

\subsection{Incomes (Values) of Lumber (Raw Material Cost) Versus Garden Furniture (Income after Further Processing)}

The general average recovery rate of $59.07 \%$ for converting kiln-dried lumber to furniture that affected costs and incomes appear to be a little higher than some ranges for the general average recovery rates of converting logs to lumber reported in literature: $30-70 \%$ [12], 20-40\% [29], 28$64 \%$ [30], and $43.5-70.6 \%$ [31]. Thus it could be said that, the recovery rate of converting lumber to garden furniture appears to be similar to that of converting logs to lumber.

Generally, the annual average value $/ \mathrm{m}^{3}$ of kiln-dried lumber was $€ 367.997$ (Ghф 419.517). The general average recovery rate of $59.07 \%$ for converting kiln-dried lumber to garden furniture, translates into the need of $1.693 \mathrm{~m}^{3}$ of lumber to produce $1 \mathrm{~m}^{3}$ of garden furniture. Hence the FOB value of kiln dried lumber needed to produce $1 \mathrm{~m}^{3}$ of garden furniture was found to be $€ 623.019$ ( $€ 367.997 \times 1.693 \mathrm{~m}^{3}$ ) (Plate 1). This appears to agree with [23] that recovery rates in the timber industry swells up the raw material cost. However, individual wood species used to produce garden furniture in Ghana were found to have varied values for their lumber, ranging from average value of $€ 657.26$ for Odum (Milicia excelsa) to $€ 275.09$ for Wawa (Triplochiton seleroxylon).

Generally, garden furniture registered an average FOB value of $€ 2,000.050$ equivalent to $\mathrm{GH} \notin 2,280.057$. 'Other income' of $€ 73.078 / \mathrm{m}^{3}$ was also realised from the byproducts of the production process, hence, garden furniture production yielded an average income of $€ 2,073.128 / \mathrm{m}^{3}$. Individual wood species used to produce garden furniture were found to yield values ranging from $€ 2,530.180 / \mathrm{m}^{3}$ for teak to $€ 792.950 / \mathrm{m}^{3}$ for albizia (Albizia ferruginea). The relatively low average value $/ \mathrm{m}^{3}$ of kiln-dried lumber could be attributed to the dominance of Wawa (Triplochiton seleroxylon) with relatively low average value $/ \mathrm{m}^{3}$ of $€ 275.09$ but had as high as over $60.0 \%$ in volume whereas species with higher values for their lumber like odum $\left(€ 657.26 / \mathrm{m}^{3}\right)$, had only about $29.0 \%$ of the total volume of kiln-dried lumber exported from Ghana during the period [3, 18 - 19].

On the other hand, the high value $/ \mathrm{m}^{3}$ of furniture could be attributed to the fact that it is a tertiary product and commands higher price than lumber [7]. FOB values of furniture recorded by [3, 14, 19] confirm this assertion by [7], as almost all the wood species for garden furniture had values of at least $€ 790.00 / \mathrm{m}^{3}$.

\subsection{Total Cost of Producing Garden Furniture}

In general, the average incremental/differential cost of further processing kiln-dried lumber to produce $1 \mathrm{~m}^{3}$ of garden furniture $(€ 1,335.958)$ (Table 3.3$)$ represented about $66.80 \%$ of the general average FOB value of garden furniture. This appears to corroborate with literature that manufacturing cost in the forest product industry is in the range of $60-70 \%$ 
[25]. It follows then that besides the raw material cost (value of kiln-dried lumber used), it costs an extra amount equivalent to $66.80 \%$ of the FOB value of each $\mathrm{m}^{3}$ of garden furniture before it could be produced and sold. This also means that, under similar conditions of cost build-up of the company, any wood species that does not have about $€ 1,336$ value difference between its kiln-dried lumber and its garden furniture cannot be profitable, no matter the recovery rate of that species.

Also, this total incremental/differential cost also represents about $214.43 \%$ of the FOB value (€623.019) of the volume of lumber needed to produce $1 \mathrm{~m}^{3}$ of garden furniture. This means that, in general terms, besides the raw material cost (value of volume of lumber used), further processing lumber to $1 \mathrm{~m}^{3}$ of garden furniture for export will cost additional amount equivalent to $214.43 \%$ of the FOB value of the volume of lumber to be used. This cost implies that, before a producer can break-even and make profits on every $\mathrm{m}^{3}$ of garden furniture produced, the percentage difference in value $/ \mathrm{m}^{3}$ between the total volume of kiln-dried lumber needed and the income to be obtained from the furniture to be produced (FOB value + income from by-products) should not be less than $214.43 \%$ of the FOB value of the lumber.

This seeming huge cost of further processing lumber to garden furniture agrees with the assertion by [32] that, Africa's poor export performance has mainly been due to high production costs and unfavourable financial and business policies, like those on taxes and levies by African governments.

\subsection{Profitability of Further Processing Lumber to Garden Furniture}

\subsubsection{Scenario Analyses}

The scenario analyses revealed that further processing kiln-dried lumber to garden furniture is generally likely to provide additional incomes in the range of $€ 66.077$ (for the worst case scenario) to $€ 334.414$ (for the best case scenario), for every $1.693 \mathrm{~m}^{3}$ of lumber used to produce and export $1 \mathrm{~m}^{3}$ of garden furniture. Among the individual wood species, the three profitable species had additional incomes in the highest range of $48.14 \%$ to $123.63 \%$ (for mixed redwood), to the lowest range of $37.59 \%$ to $9.44 \%$ (for teak) if the lumber used to make $1 \mathrm{~m}^{3}$ of their garden furniture was exported. These therefore appear to disagree with [6] where $1 \mathrm{~m}^{3}$ of garden furniture from all the species had profit margins ranging from $46.37 \%$ (for emire) to $440.66 \%$ (for akasaa) when compared to the FOB value to be obtained from export of the quantity of lumber used. This disagreement could be attributed to the total production/processing cost of furniture which was not considered by [6]. However, if controllable costs within the production costs build-up are controlled and avoidable costs avoided to reduce the cost of production, these profit margins could be improved further [7, 26]. Results from the scenario analysis imply that if wood is exported in the lumber form instead of further processing it to tertiary wood products like garden furniture, all these additional incomes and other benefits of the production process, like direct and indirect employment are lost. In another perspective, it could also mean that, all such additional incomes plus the direct and indirect employment, which further processing lumber to garden furniture would have provided, turn to be opportunity costs of exporting lumber instead of further processing them to garden furniture before export.

As a result, exporting wood in the lumber form could be a great economic loss to the nation. Moreover, whenever wood is exported in the lumber form, people are denied of the offcuts and wood shavings from the furniture processes, which are also put to several uses, including fuelwood. These and other factors might be some major contributions regarding the felling of very young trees for fuelwood, and other uses, which put the sustainable utilization of the timber resources under threat.

Other implication of these results is that converting kilndried lumber to garden furniture is generally profitable, especially for wood species such as odum (Milicia excelsa), mixed redwood, and teak (Tectona grandis). These wood species can be considered for the conversion of their kilndried lumber to garden furniture for the export market since an economist or a business person would select those outcomes that could maximise financial returns and minimise costs [24]. These results also have a very helpful implication for Ghana's afforestation and reforestation efforts. One of the companies contracted to engage in afforestation and reforestation of degraded forests is "Form Ghana", which has categorised the work into 3 major sections. These categories and their allocated portions of the 15,000 ha of degraded forests to be regenerated include: teak plantation $=$ as much as $86 \%$, indigenous tree plantation $=$ only $3 \%$ and buffer restoration $=11 \%$ [33]. Economic reason of providing higher value was one major reason for allocating as high as $86 \%$ of the area to teak plantation [33], but from this study and in terms of value-addition especially furniture production, the mixed redwoods such as utile and edinam and odum (indigenous trees) could yield higher economic value than teak. Even in terms of lumber, odum has higher value in the export market than teak by about 5.2\% (Table 2). Thus stakeholders in the afforestation industry should consider allocating substantial area for the planting of more of the indigenous trees like the mixed redwoods and odum which provide higher economic values both in lumber form and also when further processed into a tertiary product like garden furniture. If this is done, much of such wood species will then be available for both lumber and furniture producers. This will in turn avoid unnecessary competition for the species and also keep the furniture firms in operations so as to offer employment to contribute towards the enhancement of the economic lives of people and the nation at large.

\subsubsection{Time Value of Money}

It may be argued that it is worthwhile for a businessman to export kiln-dried lumber and obtain its FOB value early enough and invest it for interest instead of engaging in further processing the lumber to furniture which demands 
spending additional money and also delaying the FOB value to have been obtained from export of the kiln-dried lumber. Time value of money proved that, at a risk-free-rate of interest, the compound interest that could be accrued from investing the total cost incurred in producing $1 \mathrm{~m}^{3}$ of garden furniture, at a risk-free rate of return, represented a minimum of $1.56 \%$ to a maximum of $6.93 \%$ relative to the FOB value (€533.180), which lumber exporter would have obtained from exporting the wood used to produce garden furniture as kiln-dried lumber. However the additional incomes that represented a minimum of $12.39 \%$ to a maximum of $62.72 \%$ obtained from garden furniture production (Table 4), relative to the same lumber FOB value (€533.180) are far higher than the risk-free compound interest to be accrued from investing the FOB value of lumber in addition to the extra money needed to process lumber to furniture.

The foregoing imply that if the company spends even one month (a week more than its maximum delivery time as was told by the company's production manager) to process kilndried lumber to garden furniture, it will still be more profitable than exporting the wood as lumber, receive the FOB value of lumber early enough, add the extra monies that need to be spent in producing the furniture and investing all such monies at a risk-free-rate of return compounding weekly for four weeks. Therefore, it appears clearly that spending extra monies and time to further process kiln-dried lumber to garden furniture could generally be more profitable than exporting the wood in the lumber form.

\section{Conclusions and Recommendations}

This study was conducted to estimate incomes and costs, and to also perform scenario analysis to estimate possible profits in further processing kiln-dried lumber in general and for some specific species to garden furniture in Ghana for the export markets. Based on the results, the following conclusions and recommendations were made:

1. Generally, $1 \mathrm{~m}^{3}$ of garden furniture could yield an average income/value of about $€ 2,073.128 / \mathrm{m}^{3}$ depending on the individual wood species. Income from by-products is also of vital importance, hence efforts should be made at all times to market them.

2. Raw material (kiln-dried lumber) cost depends on the wood species concerned and its recovery rate, and the general average total incremental/differential processing cost needed to produce $1 \mathrm{~m}^{3}$ of garden furniture is about $€ 1,336$ (about $66.80 \%$ of FOB value of the furniture). And this percentage is comparable to findings in literature.

3. From scenario analysis, further processing lumber to garden furniture, $1 \mathrm{~m}^{3}$ of garden furniture produced could result in additional incomes/values ranging from $12.39 \%$ (worst case scenario) to $62.72 \%$ (best case scenario) in relation to the FOB value of the quantity of lumber used. Moreover, out of nine individual species, three; odum, mixed redwood and teak were the profitable species with mixed redwood and teak obtaining the highest and lowest additional profits respectively ranging from $48.14 \%$ to $123.63 \%$ and $37.59 \%$ to $9.44 \%$ of the FOB value of their kiln-dried lumber. Thus, incurring extra cost to convert kiln-dried lumber to garden furniture appears generally profitable. However, those from Iroko/odum, mixed redwoods and teak are especially more profitable than the other species.

Thus, from the scenario analyses, it appears that maintaining costs while increasing productivity (scenario 5) is the best combination of cost and volume of production for better profit levels in garden furniture production. Hence adopting this scenario could improve the economic fortunes of the firms to keep them in operation for growth and development.

4. It is therefore being recommended that if possible, Government should provide some tax and other incentives that will attract investors in the wood processing industry, to add more value to the timber resource through further processing of kiln-dried lumber to garden furniture and other tertiary wood products before export. This will increase profit levels of the firms to aid expansion which will in turn generate more employment to improve economic lives of the citizenry and subsequently help the government to obtain more tax revenues in terms of income taxes for national development.

5. Moreover, government agencies and other entities charged with the responsibilities of afforestation, reforestation and regeneration of degraded forests in Ghana should consider allocating appreciable land areas for the planting of odum (milicia excelsa) and mixed redwoods (such as edinam - Entandrophragma cylindricum and utile - Entandrophragma utile) in addition to teak which appeared to be the tree species whose lumber and furniture values make it possible for better profits to be obtained in manufacturing valueaddition products like garden furniture.

\section{References}

[1] Alexander Rose Ltd. (2005). Fine Quality Traditional Garden Furniture, Alexander Rose Ltd, West Sussex. U.K. pp 1-5.

[2] Plow, and Heart Inc., (2006). Furniture Buying Guide. Retrieved, April, 2006 from www.plowhearth.com/ Outlet Store.

[3] TIDD. (2003). Exporters performance/moving species/direction of trade-Lumber (KD), flooring and furniture parts. Report on Export of Wood Products for December. (pp. 1-45). Takoradi. Ghana. Data Processing Section of TIDD.

[4] Ratnasingam, J., (1998). The South-East Asian Furniture Industry Siege, Southern African Wood and Timber Times 24 (1), South Africa. PP 68-72.

[5] Waters, M. M. (1970). Woodwork - A course for First Exanimations, R \& R Clark, Ltd. London. Great Britain. pp. 67-136. 
[6] Dadzie P. K., Amoah, M. \& Tekpetey S. L (2014). Preliminary Assessment of Wealth Creation in Wood Products' Business in Ghana: The Perspective of Lumber and Furniture Production and Implications for Entrepreneurship, International Journal of Business and Economic Research, 3(6): 243-249. doi: 10.11648/j.ijber.20140306.15. Retrieved, December 2014 from http://www.sciencepublishinggroup.com/j/ijber

[7] Garrison, R. H. (1991). Managerial Accounting - Concepts for planning, control and decision making, (6th ed.). Von Hoffmann Press Inc., New York. U.S.A. pp 503-770

[8] Engler, C. (1990). Managerial Accounting, (2nd ed.). R. R Donnelley \& Sons Company, New York. U.S.A. pp 114-618.

[9] ROSS, A. Stephen, Westerfield, Randolph W. and Jordan, Bradford D. (2000). Fundamentals of Corporate Finance, $5^{\text {th }}$ Edition, Irwin McGraw-Hill, London. U.K. pp. 317-335.

[10] Kula, E. (1994). Economics of Natural Resources, The Environment and Policies, $2^{\text {nd }}$ Edition, Chapman \& Hall, London. U.K. pp. 89-98.

[11] Eckles, R. W., Carmichael T. L. and Sarchet, B. R. (1981). Supervisory management. (2nd ed.). John Wiley and Sons, New York. U.S.A. pp1-50.

[12] Desch, H. E., and Dinwodie, J. M. (1996). Timber structure properties, conversion and use. $7^{\text {th }}$ Edition, Macmillan Press, London. U. K. 306pp.

[13] Haygreen, J. G. and Bowyer J. L. (1996). Forest Products and Wood Science-An Introduction, $\left(3^{\text {rd }}\right.$ ed), IOWA State University Press, Ames. U.S.A. 485pp.

[14] TIDD. (2005a). The First 30 out of 126 Exporters of all wood products, Jan-Feb 2005. Wood Products' Export Report for February 2005, Data Processing Section of TIDD, Takoradi, Ghana. pp. 4-32.

[15] Asumadu, K. (1997). Forest Resources-Declining Nature, Competitiveness in International Trade, Policy and Institutional Changes to promote investment. In AFORNET Policy Brief No. 8, Wood Based Industries in Sub-Saharan Africa. pp. 12-18.

[16] Forestry Department (2001) Forestry sector outlook studies: Ghana Ministry of Lands and Forestry Country Report FOSA/WP/12. Accra, Ghana.

[17] Ghana Statistical Services (2007) Economic Survey 20012005, Ghana Statistical Service, Accra, Ghana. 131pp.

[18] TIDD. (2005b). Exporters performance/moving species/direction of trade-Lumber (KD), flooring and furniture Parts. Report on Export of Wood Products for December 2005, Data Processing Section of TIDD, Takoradi, Ghana. pp. 3-54.

[19] TIDD. (2004). Exporters performance/moving species/direction of trade-Lumber (KD), flooring and furniture part. Report on Export of Wood Products for December 2004, Data Processing Section of TIDD, Takoradi, Ghana. pp. 2-52.
[20] Crystal, Alec K. and Lipsey, Richard G. (1997). Economics for Business and Management, Oxford University Press Inc. New York. U.S.A. pp. 117-352.

[21] Glastra (1991) in Ayivor J S, Gorden C, Adomako J K, and Ntiamoah-Baidu Y (2011) Challenges of managing forest reserves: Case study of Atewa range forest reserve, Ghana, Nature and Faune 25(2) 56- 63.

[22] Acquah ET and Whyte C (1998) The potential for Ghana's wood/wood products in the U.S market Office of Sustainable Development, USAID Africa Bureau. pp. 8 - 133.

[23] Tillman D. A. (1985). Forest Products Advanced Technologies and Economics Analyses, Academic Press Inc., Orlando, Florida. U.S.A. 283pp.

[24] Gregory, R. G. (1987). Resource Economics for Foresters. John Wiley \& Sons Inc. New Jersey. Canada. pp. 1-145.

[25] Quesada-Pineda, H. (2010). The ABCs of Cost Allocation in the wood products industry: Applications in the furniture industry, Virginia Cooperative extension publication No. 420147. pp. 1-10. Retrieved, May, 2012, from http://pubs.ext.vt.edu/index.html.

[26] Corrado, C. J., and Jordan, B. D. (2000). Fundamentals of Investments-Valuation and Management, Irwin McGraw-Hill, Boston. U.S.A. pp. 3-31.

[27] Hilton, R. W., Maher, M. W. and Selto, F. H. (2000). Cost Management -Strategies for Business Decision, (International ed.). McGraw-Hill Companies, Inc., Boston. U.S.A. pp. 105588 .

[28] BPP Publishing Ltd. (2001). Financial Information for Management, $1^{\text {st }}$ Edition, ACCA Study Text, BPP Publishing Limited, London. U.K. pp. 50-410.

[29] Agyarko T. (2001). FAO Corporate document Repository FOSA Forestry Outlook Study for Africa. Country Report Ghana, Ministry of Lands and Forestry. $2^{\text {nd }}$ draft FOSA/WP/12. 49pp.

[30] Gyimah, R. and Adu, G. A. (2009). A pilot study on sawnwood conversion efficiency in selected sawmills in Ghana. A draft report presented at a National workshop in Kumasi, March, 2009. 52pp.

[31] Owusu, F. W., Appiah, J.K., Damnyag, L., and Blay, D. (2011) Comparative anaylsis of recovery efficiencies of some milling techniques in Ghana, Ghana Journal of Forestry, Vol. 27. pp. 87-100.

[32] Amjadi, A. and Yeast, A. J. (1995). Have Transport Costs contributed to the relative decline of Sub- Saharan African Exports? Some preliminary empirical evidence. Policy Research Working Paper, 1 (WPS 1559 of 2005). Retrieved, May 2005 from www.econ.worldbank.org/external.

[33] Sools R, de-wilde R, Tellenear M (2003) Reforestation of degraded forest reserves in Ghana, Form Ghana Project Desing Document. 83pp. 